\title{
Obtížnost a zaujetí úkolem v matematice
}

\author{
Difficulty and task interest in mathematics
}

\author{
Eliška Kmínková, Isabella Pavelková
}

\begin{abstract}
Abstrakt: Cílem předkládané studie je zmapovat vliv stoupající obtížnosti na zaujetí školním úkolem. Teoreticky analyzujeme především následující motivační proměnné: postoj k předmětu, individuální zájem, situační zájem, aktuální zájem, cílová orientace, flow zážitek a výkonová motivace. U jednotlivých motivačních zdrojů budeme tematizovat jejich dopad na zaujetí žáka úkolem. $\mathrm{V}$ druhé části studie budeme teoretická východiska prověřovat $\mathrm{V}$ experimentu, který byl realizován $\mathrm{v}$ roce 2010 na pražské základní škole $\mathrm{v} 9$. trrídě v předmětu matematika. Data byla získávána na základě dotazníkového šetření.
\end{abstract}

Klíčová slova: pedagogická psychologie, motivace, obtížnost předmětu, zaujetí úkolem, postoj k předmětu, flow zážitek.

\begin{abstract}
The objective of the presented study is to map how various motivational factors influence the pupils' captivation by school work (school tasks). We analyse especially the following motivational variables: individual interest, situational interest, target orientation, output motivation and flow experience. We verify the theoretic fundaments in an experiment that was realised in 2010 at grammar school in mathematics.
\end{abstract}

Keywords: educational psychology, motivation, task difficulty, task interest, attitudes, flow experience

\section{1 Úvod - teoretické zakotvení}

V prezentovaném výzkumu se zaměřujme na problematiku žákovského zaujetí školní prací. Zajímá nás, jaké motivační faktory hrají roli při školní práci, konkrétně při práci na zadané matematické úloze. Školní situační motivace, která se projevuje především v zaujetí úkolem, je ovlivněna celou řadou motivačních faktorů. Diskutovány jsou v odborné literatuře především tyto motivační proměnné:

\subsection{Zájem}

a) Individuální zájem, který také můžeme označit jako koníček, hobby a může jím být např́iklad sport, četba, sběratelství apod. Odborníci (Rheinberg, 1989; Schiefele, 1998) uvádějí, že zájem způsobuje např. tyto jevy: arousal, flow zážitky, zlepšení pozornosti, strategii důkladného čtení, tvorbu poznámek, podtrhávání. Podle Schiefeleho (Hoffmann, Krapp, Renniger, \& Baumert, 1998) teoretici i praktici v oblasti zájmu se shodují na tom, že zájem hraje základní roli v učení. Problémem je ale nedostatek studií v této oblasti. Některé výzkumy (Oerten, 1995 in Krapp, 1998) ale ukazují, že škola nemusí být pro rozvoj zájmů zvlášt' podnětná a někdy může působit až dysfunkčně. Důležitou roli zde hraje osobnost učitele a učební prostř̌edí ve trrídě. Individuální zájmy žáků jsme zjišt’ovali u žáků maturitního ročníku na gymnáziu v rámci diplomové práce (Kmínková, 2009). Žáci uvedli sice relativně 
velkou škálu zájmů, ale uváděné zájmy šlo jen velice těžko v hodinách matematiky využít. Mezi individuálními zájmy a zaujetím úkolem v matematice jsme nenašli souvislost.

b) Situační zájem je dalším z druhů zájmů. Podle Hidi a Anderson (1992 in Chen, Darst, \& Pangrazi, 2001) ho lze definovat jako přitažlivý efekt aktivity nebo učební úlohy na jedince. Situační zájem Schraw (2001) definuje jako „dočasný zájem“, který vzniká spontánně díky faktorům z prostředí, jako jsou instrukce k úkolu nebo přitažlivý text. Situační zájem lze využít k upoutání pozornosti, jeho efekt je však spíše krátkodobý, oproti individuálnímu zájmu, který působí dlouhodobě, ale jen v určité, pro jedince specifické oblasti. Situační zájem lze vytvořit v libovolném tématu. Podle Chen, Darst a Pangrazi (2001) jsou zdroje situačního zájmu tyto: novost/originalita, výzva, zkoumání záměrů, upoutání pozornosti a moment radosti/bezprostředního potěšení. Situační zájem může být podle Schraw (2001) založen na třech aspektech: na textu založený, na úkolu založený a na znalostech založený.

c) Cílová orientace/aktuální zájem. V naší výzkumné sondě chápeme cílovou orientaci jako dopad cílové orientace do aktuální činnosti jedince. Např́klad když žák potřebuje složit přijímací zkoušku z matematiky na vysokou školu, bude pravděpodobně v hodinách matematiky aktivní, i když ho jinak matematika vůbec nezajímá. Podle Köllera (1998) je cílová orientace silným motivačním činitelem, kdy jedinec jedná ne podle aktuálních potřeb, zájmů, ale podle toho, jaký cíl je pro něj důležitý. Ve škole takovým cílem může být např́iklad další studium, které přijde po dokončení školy apod. Zde je nutné upozornit na to, že se shodujeme s Köllerem (1998) na tom, že jedinec nejedná jen podle aktuálních potřeb, zájmů, tedy podle toho, co jedince zajímá ten den, čeho $\mathrm{v}$ ten den, $\mathrm{v}$ tu chvíli, chce dosáhnout, ale podle potřeb a zájmů, které hodlá uskutečnit v budoucnosti. Tyto zájmy a potřeby se ale promítají do aktuální činnosti jedince. Proto zde dochází k terminologickým obtížím při použití pojmu „aktuální zájem“, který není v literatuře dosud jasně vydefinován. Ve svém výzkumu Köller (1998) zjistil, že cílová orientace a zájem jsou dva rozdílné koncepty. Ukázalo se, že matematické zájmy nemají velký vliv na učení. V tomto výzkumu se tedy nepotvrdilo, že zájem podporuje akademické učení. Cílová orientace měla však významný efekt na učení. Výsledky diplomové práce (Kmínková, 2009) ukazují, že mezi cílovou orientací a zaujetím v matematice existuje velmi pravděpodobně silná vazba.

\subsection{Flow zážitek}

$\mathrm{V}$ životě se u některých lidí setkáme s velkým nasazením a zaujetím a zároveň se spokojeností při vykonávání určitých činností, přestože se jim nedostává vnější podpory a jen těžko se dá říci, že práci dělají z nějakého zájmu. Takové hluboké zaujetí prací či činností je spojováno s tzv. flow motivací. V širších definicích vnitřní motivace bývá tato motivace zahrnována. Flow motivace je velmi cenná vhledem ke kvalitě práce a silnému vnitřnímu uspokojení, pro hlubokou koncentraci při činnosti, dělání naplno a splynutí s prací.

\subsection{Výkonová motivace}

Vztah k výkonu není u všech žáků stejný. Značná část pocit’uje v úkolové situaci sice potřebu dosáhnout úspěšného výkonu, současně se však do jisté míry i obává neúspěchu a pocituje potřebu vyhnout se mu. Dủležitost výkonové motivace ve škole byla potvrzena v mnoha výzkumech (Hrabal \& Pavelková, 2011; Rheinberg, 1997, 2000 a další). V rámci pilotní sondy jsme se zatím zabývali jen obavou z neúspěchu. 


\subsection{Postoj $k$ předmětu}

Motivovanost a postoj žáka $\mathrm{k}$ určitému předmětu hrají pravděpodobně významnou úlohu při jeho úspěšnosti ve škole. Podrobně jsme se této problematice věnovali v monografii. Jaký jsem učitel (Hrabal \& Pavelková, 2010).

\section{Realizovaný výzkum - Cíl pilotní studie}

Cílem předkládané pilotní studie bylo orientačně zmapovat vybrané motivační faktory, které mohou ovlivnit zaujetí matematickým úkolem různé obtížnosti. Prověřujeme především následující motivační proměnné: postoj k předmětu, situační zájem, cílová orientace aktuální zájem a flow zážitek, obava z neúspěchu.

\section{Místo a čas realizace}

Výzkum byl realizován na konci školního roku 2009/2010 na základní škole (9. ročník). Jednalo se o školu sídlištní, situovanou na okraji Prahy. Škola má 300 žáků.

\section{Výzkumný vzorek}

Výzkumné sondy se zúčastnilo celkem 22 žáků, 10 chlapců a 12 dívek ve věku od 15 ti do 17 ti let. Třída je národnostně rozmanitá, třídu navštěvuje několik žáků z národnostních menšin (Vietnam, Ukrajina).

\section{Způsob získávání dat - metoda}

Data byla $\mathrm{v}$ předmětu matematika získávána na základě dotazníkového šetření. Žáci vyplňovali celkem 3 dotazníky. Každý dotazník obsahoval 5 otázek před úkolem, zadání úkolu a prostor k jeho splnění a 13 otázek po úkolu - v položkách dotazníku před a po splnění úkolu byli operacionalizované výše uvedené motivační proměnné. K prvnímu dotazníku, který žáci vyplňovali, byl na začátku přidán ještě jeden list, kde žáci popisovali svůj postoj $\mathrm{k}$ předmětu. Úkoly v dotaznících byly konstruovány s narůstající obtížností, tzn., první byl nejlehčí a poslední byl nejobtížnější. Všechny tři úkoly se týkaly konstrukce trojúhelníků.

- Úkol č. 1 - Sestroj pravoúhlý trojúhelník $\mathrm{ABC}$, pravý úhel při vrcholu $\mathrm{C}$, pokud je dáno: $\mathrm{c}=5 \mathrm{~cm}, / \angle \mathrm{ABC} /=50^{\circ}$. (úloha má pouze jednu možnost jak postupovat). Maximum bylo 9 bodů za správné řešení úlohy.

- Úkol č. 2 - Sestroj trojúhelník $A B C$, pokud znáš: $a=4,5 \mathrm{~cm}, \mathrm{~b}=5 \mathrm{~cm}, \mathrm{vb}=4 \mathrm{~cm}$. (úloha má více možností jak postupovat). Maximum bylo 9 bodů za správné řešení úlohy.

- Úkol č. 3 - Sestroj trojúhelník $\mathrm{ABC}$, pokud je dáno: $\mathrm{c}=5 \mathrm{~cm}, \mathrm{vc}=4 \mathrm{~cm}, \gamma=90^{\circ}$. Maximum bylo 10 bodů za správné řešení úlohy.

\section{Popisná statistika}

Celkově je prospěch této třídy v matematice dobrý. Většina žáků (13) je hodnocena známkou 1 či 2, matematiku hodnotí jako předmět velmi oblíbený či oblíbený, ani obtížný ani snadný, 
vidí ho jako velmi významný či významný, velmi zajímavý či zajímavý. 10 žáků se cítí být na matematiku velmi nadaní či nadaní, 7 stř̌edně nadaní, 5 málo nadaní či nenadaní. 20 žáků se při tomto předmětu nenudí nebo nudí málokdy. Chlapci mají matematiku více oblíbenou, považují ji za obtížnější, významnější, zajímavější, cítí se být na ni více nadaní a více se v ní nudí, než děvčata. Většina chlapců (70 \%) se chystá v budoucnosti maturovat z matematiky a budou se hlásit na VŠ, kde budou matematiku potřebovat, oproti většině dívek (75\%), které se nechystají maturovat z matematiky ani v dalším studiu neplánují matematiku využít. Počet žáků, kteří uvedli, že je úkol zaujal při jeho vypracování, byl pokaždé stejný nebo větší, než počet žáků zaujatých před úkolem. Stoupajíci obtizznost: a) zaujetí úkolem - počet zaujatých žáků před úkolem výrazně klesl u třetího (nejobtížnějšího) úkolu, počet žáků zaujatých při úkolu se s narůstající obtížností úkolů téměř neměnil; počet nezaujatých ale stoupal; $b$ ) aktivita - celkový počet aktivních žáků při úkolech s nárůstem obtížnosti úkolů mírně stoupal. Zajímavý je fakt, že 3. úkol nebyl ohodnocen žáky jako nejobtížnější. Pro žáky byl nejvíce obtížný úkol 2. Vnímaná obtížnost učitelem tedy neodpovídala vnímané obtížnosti úkolu žáky. Celkově žáci byli v úkolech s narůstající obtížností stále úspěšnějšší, což mohlo být dáno tím, že látka na sebe navazovala a žáci znalosti získané v úkolu mohli částečně využít v následující úloze.

\section{Explorativní část studie}

1. Existují statisticky významné vazby mezi zaujetím úkolem a vybranými motivačními faktory v úkolech různé obtížnosti?

2. Existují typické motivační a výkonové konstelace u skupin žáků, kteří jsou zaujatí úkolem a kteří nejsou zaujatí úkolem?

Ve stati vybereme jen některé výsledky týkající se druhé otázky, a to s oporou o faktorovou analýzu (Rotovaná forma - metoda Varimax) - podrobné údaje u autorek. Porovnáme-li rotované formy faktorové analýzy jednotlivých úkolů, tak nám ve všech úkolech vystupuje faktor, který můžeme označit jako faktor negativního postoje $k$ matematice. Faktor sdružuje žáky, kteří nemají matematiku oblíbenou, považují ji za obtížnou, nezajímavou, cítí se pro ni nenadaní a částečně se v ní nudí. Úkoly se jim nechce dělat, nezaujaly je a nejsou v nich aktivní ani soustředění, úkoly jim nebyly úplně jasné a potřebovali by pomoc, v úkolech jsou neúspěšní. Faktor můžeme komentovat i obráceně. Za zmínku stojí i faktory, které nacházíme také u všech typů obtížnosti úkolu a které můžeme nazvat - faktor nevýznamnosti matematiky - tyto faktory sdružují žáky, kteří připisují matematice malý význam, úkoly je nezaujaly a myslí si, že získané dovednosti v úkolu v životě nevyužijí.

\section{Interpretace výsledků a diskuse}

Výsledky faktorové analýzy naznačují, že neexistují, př́iliš velké motivační rozdíly u úkolů různé obtížnosti, kazuistiky jednotlivých žáků (v textu již nemáme místo na jejich prezentaci) však na důležitost faktoru obtížnosti upozorňují. U některých žáků se postoj k předmětu přelévá do výkonu v úkolu, kdy neochota začít pracovat na úkolu je nezávislá na jeho obtížnosti, někteří žáci však reagují na různou obtížnost jednotlivých úkolů. Při úkolu se pak vytvář́ specifická motivační situace, kde se u některých žáků projevuje vliv obtížnosti úkolu a sebedůvěry žáka. V souladu s dřivějšími výzkumy (Hrabal, Pavelková 2010) byl potvrzen velký význam postoje k předmětu. Výsledky ukazují, že učitelé se ve škole setkávají $\mathrm{z}$ hlediska motivace žáků s velmi diferencovanou situací. Na jedné straně se setkávají s poměrně stabilně motivovanými žáky, ale zároveň pracují s žáky nemotivovanými 
s negativním postojem k předmětu, kteří nejsou zaujati školními úkoly, at' jsou jakékoliv obtížnosti. Výzkum ukázal, jak je složité stanovení motivačních faktorů rozhodujících o tzv. situační motivaci, jak komplikovaná je otázka tzv. obtížnosti úkolu a motivačního podmínění úspěšnosti v úkolu. Závěrem chceme zdůraznit, že výsledky této pilotní studie prokázaly smysluplnost zkoumání tzv. situační motivace, i když jsme se nevěnovaly všem jejich složkám. Podněty, které studie přinesla, budou využity pro vytváření hypotéz pro další výzkumy v této oblasti.

\section{Literatura}

Hrabal, V., \& Pavelková, I. (2011). Jaký jsem učitel. Praha: Portál.

Chen, A., Darst, P. W., \& Pangrazi, R. P. (2001). An examination of situational interest and its sources. British Jorunal of Educational Psychology, 71, 383-400.

Kmínková, E. (2009). Zaujetí při matematice a orientace na matematiku. (Diplomová práce). Praha: UK v Praze.

Köller, O. (1998). Different aspects of learning motivation: The impact of interest and goal orientation on scholastic learning. In L. Hoffmann, A. Krap, K. A. Renniger, \& J. Baumert (Eds.), Interest and learning (pp. 317-326). Kiel: IPN.

Krapp, A. (1998). Interesse. In D. H. Rost (Hrsg.). Pädagogische psychologie (pp. 213-218). Weinheim: PVU.

Rheinberg, F. (1997, 2000) Motivation (2, 3 Aufl.). Stuttgart: Kohlhammer.

Schiefele, U. (1998). Individual interes and learning - What we know and what we don't know. In L. Hoffmann, A. Krapp, K. A. Renniger, \& J. Baumert (Eds.), Interest and Learning. Kiel: IPN.

Schraw, G., Flowerday, T., \& Lehman, S. (2001). Increasing situational interest in the Classroom. Educational Psychology Review, 13(3), 211-224.

Schraw, G., \& Lehman, S. (2001). Situational interest: A review of the literature and directions for future research. Educational Psychology Review, 13(1), 23-52.

\section{Kontakt}

Doc. PhDr. Isabella Pavelková, CSc.

Mgr. Eliška Kmínková

Univerzita Karlova v Praze

Pedagogická fakulta, Katedra psychologie

e-mail: jfpavelka@volny.cz

EKminkova@seznam.cz

\section{Bibliografické údaje}

Kmínková, E., \& Pavelková, I. (2011). Obtížnost a zaujetí úkolem v matematice. In T. Janík, P. Knecht, \& S. Šebestová (Eds.), Smíšený design v pedagogickém výzkumu: Sborník př̀spěvků z 19. výročni konference České asociace pedagogického výzkumu (s. 434-438). Brno: Masarykova univerzita. Dostupné z: http://www.ped.muni.cz/capv2011/sbornikprispevku/kminkovapavelkova.pdf

doi: 10.5817/PdF.P210-CAPV-2012-26 